\title{
The expression of $11 \beta$-hydroxysteroid dehydrogenase type 1 is increased in experimental periodontitis in rats
}

\author{
Takaya Nakata', Makoto Umeda², Hiroaki Masuzaki ${ }^{3}$ and Hirofumi Sawai ${ }^{4^{*}}$ (D)
}

\begin{abstract}
Background: The involvement of $11 \beta$-hydroxysteroid dehydrogenase type 1 (11ß-HSD1), which converts inactive glucocorticoids into active glucocorticoids intracellularly, in metabolic diseases and chronic inflammatory diseases has been elucidated. We recently reported that an increase in 11ß-HSD1 expression was associated with chronic periodontitis in humans irrespective of obesity. To further clarify the role of $11 \beta-H S D 1$ in chronic periodontitis, the expression of $11 \beta-H S D 1$ was investigated in experimental periodontitis model in rats.

Methods: Experimental periodontitis was induced by silk ligature of left maxillary second molars of 7-week-old male

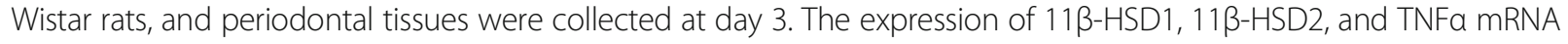
was examined using real time reverse transcription-polymerase chain reaction. The expression of TNFa was used as an indicator of inflammation. Thus, the rats in which the levels of TNFa mRNA were increased in the ligature-induced periodontitis compared with the control were analysed.
\end{abstract}

Results: The findings demonstrated that the expression of 11ß-HSD1 mRNA was significantly increased in experimental periodontitis compared with the control. The increase in the levels of 11ß-HSD1 mRNA in the ligature-induced periodontitis compared with the control was positively correlated with that of TNFa mRNA. On the other hand, the expression of 11ß-HSD2 mRNA, which inactivates glucocorticoids, was slightly decreased in experimental periodontitis. Therefore, the ratio of $11 \beta$-HSD1 versus $11 \beta-H S D 2$ mRNA was significantly higher in experimental periodontitis than in the control.

Conclusions: These results suggest that the increased expression of $11 \beta-H S D 1$, which would result in the increased levels of intracellular glucocorticoids, may play a role in the pathophysiology of experimental periodontitis.

Keywords: $11 \beta$-Hydroxysteroid dehydrogenase type 1, Glucocorticoids, Chronic periodontitis, Experimental periodontitis, Inflammation

\section{Background}

The involvement of cortisol, a major glucocorticoid hormone in humans, in chronic periodontitis has been investigated. Serum and salivary cortisol levels were reported to be correlated with measures of chronic periodontitis [1-5]. In animal experiments, ligature-induced periodontitis was more severe in hypothalamic-pituitaryadrenal (HPA) high-responding Fischer 344 rats than in MHC-identical but HPA low-responding Lewis rats.

\footnotetext{
*Correspondence: sawai@cc.osaka-dent.ac.jp

${ }^{4}$ Department of Internal Medicine, Osaka Dental University, Hirakata, Osaka, Japan

Full list of author information is available at the end of the article
}

Treatment with RU 486, a glucocorticoid receptor antagonist, reduced experimental periodontitis in Fischer 344 rats, suggesting that the increased glucocorticoids play a role in experimental periodontitis [6-8]. However, the mechanism by which the levels of glucocorticoids are increased and the role of the increased glucocorticoids in chronic periodontitis remain to be determined.

$11 \beta$-hydroxysteroid dehydrogenases, one of the many enzymes involved in the metabolism of glucocorticoids, catalyze the intracellular conversion between active (cortisol in humans and corticosterone in rodents) and inactive (cortisone in humans and 11-dehydrocorticosterone in rodents) glucocorticoids [9-12]. Generally, 11ß-HSD1 
activates and $11 \beta$-hydroxysteroid dehydrogenase type 2 $(11 \beta-H S D 2)$ inactivates glucocorticoids. It was reported that the expression of $11 \beta$-HSD1 was increased in adipocytes, especially in visceral fat, of patients with metabolic diseases, which suggests that $11 \beta-H S D 1$ plays a role in the pathogenesis of metabolic diseases [13-15]. Animal studies supported this notion. 11 $\beta$-HSD1-deficient mice showed attenuated glucocorticoid-inducible responses and resisted hyperglycemia on obesity or stress [16], whereas transgenic mice overexpressing $11 \beta-H S D 1$ selectively in adipose tissue developed visceral obesity that was exaggerated by a high-fat diet $[17,18]$. Furthermore, several 11ß-HSD1 inhibitors were reported to ameliorate metabolic diseases in mice $[19,20]$. Currently, several $11 \beta$-HSD1 inhibitors are being developed for the treatment of metabolic diseases, especially type 2 diabetes mellitus [21-24].

Since obesity, as well as metabolic diseases, can be regarded as chronic inflammation of adipose tissue [25, 26], the involvement of $11 \beta$-HSD1 in other chronic inflammatory diseases has been investigated. The increased expression of $11 \beta$-HSD1 was demonstrated in inflammatory bowel diseases and rheumatoid arthritis [27-30], suggesting that the increased $11 \beta$-HSD1 plays a role in chronic inflammation. We recently investigated the expression of $11 \beta$-HSD1 in periodontal tissues from patients with chronic periodontitis, and reported that the expression of $11 \beta$-HSD1, as well as the ratio of $11 \beta$-HSD1 versus $11 \beta$-HSD2, was significantly higher in chronic periodontitis than in the control irrespective of obesity [31]. In this study, to further clarify the role of $11 \beta-H S D 1$ in chronic periodontitis, the expression of $11 \beta-H S D 1$ was investigated in ligature-induced experimental periodontitis in rats.

\section{Methods \\ Animals}

Fifty six-week-old male Wistar rats were purchased from Shimizu Laboratory Supplies (Kyoto, Japan) and were maintained under specific pathogen-free conditions with food and distilled water at Osaka Dental University Animal Care. The experimental protocol was approved by the Committee for Animal Experiments of Osaka Dental University (\#14-09001), and experimental procedures were performed in accordance with the Guidelines for Animal Experiments of Osaka Dental University.

\section{Experimental periodontitis}

Experimental periodontitis was induced as described with modifications [32]. Experiments were started at 7 weeks of age. General anesthesia was induced with inhalation of isoflurane (Wako Pure Chemical Industries, Osaka, Japan) and intraperitoneal injections of pentobarbital (Kyoritsu Seiyaku Corporation, Tokyo, Japan) at $0.3 \mathrm{mg} / \mathrm{kg}$ body weight. Silk threads (5-0 Nescosuture, Alfresa Pharma Corporation, Osaka, Japan) were ligated around the cervix of the left maxillary second molars to induce experimental periodontitis. The right maxillary second molars were used as the control. Three days after the ligation, rats were euthanized with an overdose of isoflurane and pentobarbital.

\section{Micro-CT analysis}

Images of the excised maxillary bones were analysed using a micro-CT scanner, SMX-130CT (Shimadzu Corporation, Kyoto, Japan). The micro-CT parameters were set as follows: image pixel size, $512 \times 512$; voltage, $40 \mathrm{kV}$; beam current, $40 \mu \mathrm{A}$; view number, 1200 ; scaling coefficient, 10. Three dimensional images were generated using VGStudio MAX 1.2.1 software (Volume Graphics, GmbH, Germany).

\section{RNA extraction}

Periodontal tissues around the right and left maxillary second molars (for the control and periodontitis group, respectively) were excised, and then homogenized in 1 ml of TRIzol Reagent (Invitrogen, Carlsbad, CA, USA). After the addition of $0.2 \mathrm{ml}$ chloroform, the mixture was centrifuged at $12,000 \mathrm{~g}$ for $15 \mathrm{~min}$ at $4{ }^{\circ} \mathrm{C}$. The aqueous phase was transferred to a new tube and $0.5 \mathrm{ml}$ of isopropyl alcohol was added. After centrifugation at $10,000 \mathrm{~g}$ for $10 \mathrm{~min}$ at $4{ }^{\circ} \mathrm{C}$, the RNA precipitate was washed with $1 \mathrm{ml}$ of $75 \%$ ethanol and centrifuged at $7500 \mathrm{~g}$ for $5 \mathrm{~min}$ at $4{ }^{\circ} \mathrm{C}$. Then the RNA precipitate was air-dried and dissolved in RNase-free water. For determination of RNA concentration, the absorbance at $260 \mathrm{~nm}$ was measured using a spectrophotometer, SmartSpec 3000 (Bio-Rad, Hercules, CA, USA).

\section{Real time reverse transcription (RT)-polymerase chain reaction (PCR)}

As probes for PCR, TaqMan Gene Expression Assays

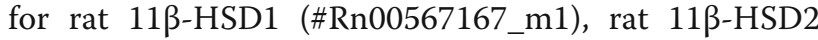
(\#Rn00492539_m1), rat TNFa (\#Rn99999017_m1), and rat glyceraldehyde-3-phosphate dehydrogenase (GAPDH) (\#Rn01775763_g1) were purchased from Applied Biosystems (Foster City, CA, USA). RT-PCR was performed using TaqMan RNA-to- $C_{\mathrm{T}}$ 1-Step Kit and StepOnePlus Real Time PCR System (Applied Biosystems, Foster City, CA, USA). Each template (20 ng RNA) was mixed with 1 $\mu \mathrm{l}$ of probe, $0.5 \mu \mathrm{l}$ of RT Enzyme Mix, $10 \mu \mathrm{l}$ of RT-PCR Mix, and Nuclease-free water was added so that the total volume of the mixture should be $20 \mu \mathrm{l}$. The mixture was incubated for $15 \mathrm{~min}$ at $48{ }^{\circ} \mathrm{C}$ for reverse transcription, followed by incubation for $10 \mathrm{~min}$ at $95^{\circ} \mathrm{C}$ for inactivation of reverse transcriptase and activation of DNA polymerase. For PCR, the mixture was incubated for $15 \mathrm{~s}$ at $95{ }^{\circ} \mathrm{C}$ for denaturing and then for $1 \mathrm{~min}$ at $60{ }^{\circ} \mathrm{C}$ for 
annealing/extension for 50 cycles. The values of $11 \beta$ HSD1, 11 $\beta$-HSD2, and TNF $\alpha$ mRNA relative to GAPDH mRNA were calculated in each sample.

\section{Histological examinations}

Another set of experiments was performed for histological examinations. After euthanasia, the rats were perfused with $10 \%$ formaldehyde neutral buffer solution (SigmaAldrich, St. Louis, MO, USA). Then the maxillary bones were excised, and fixed in $10 \%$ formaldehyde neutral buffer solution at $4{ }^{\circ} \mathrm{C}$ for 3 days. The bones were decalcified in a rapid decalcification solution, K-CX (Falma, Tokyo, Japan), at $4{ }^{\circ} \mathrm{C}$ for $24 \mathrm{~h}$, followed by conventional dehydration and paraffin embedding. After cutting into 5 $\mu \mathrm{m}$-thick sections, the specimens were deparaffinized and then stained with hematoxylin-eosin (HE) or immunostained with either anti-11ß-HSD1 antibody (Bioss, Woburn, MA, USA) or anti-11ß-HSD2 antibody (Santa Cruz Biotechnology, Dallas, TX, USA) using Envision + kit/HRP (DAB) (Dako, Glostrup, Denmark). Images were obtained using an all-in-one microscope, BZ-9000 (Keyence, Osaka, Japan).

\section{Statistical analyses}

The comparison between the control and the periodontitis group was assessed by paired $t$-test. The correlation between the increase in the levels of 11 $\beta$-HSD1 mRNA and that of TNF $\alpha$ mRNA was assessed by Pearson's correlation analysis using SPSS software version 21.0 (IBM, Armonk, NY, USA).
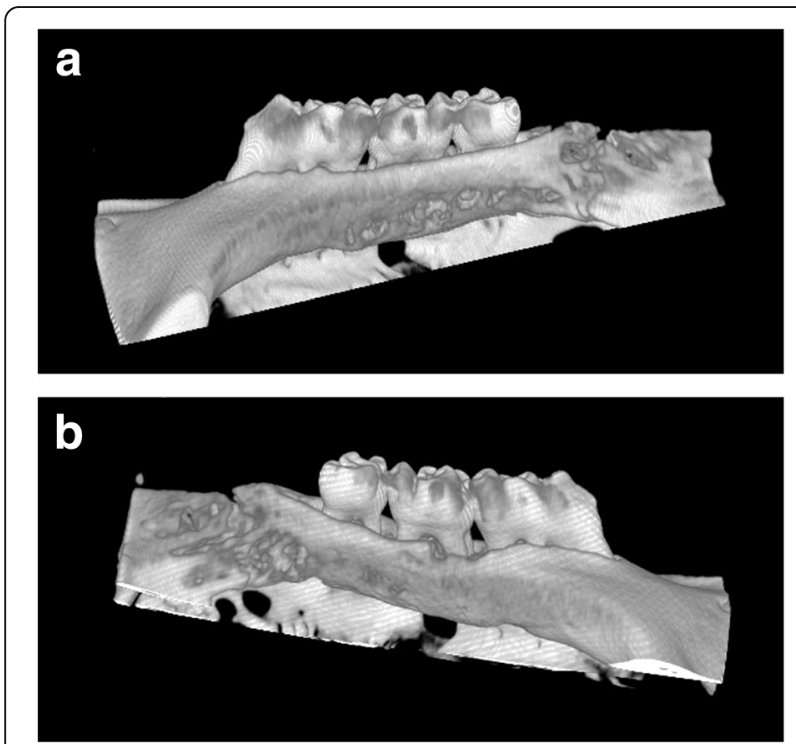

Fig. 1 Micro-CT scan of maxillary bones on the palatal side. a Control. b Ligature-induced periodontitis (after 2 weeks)
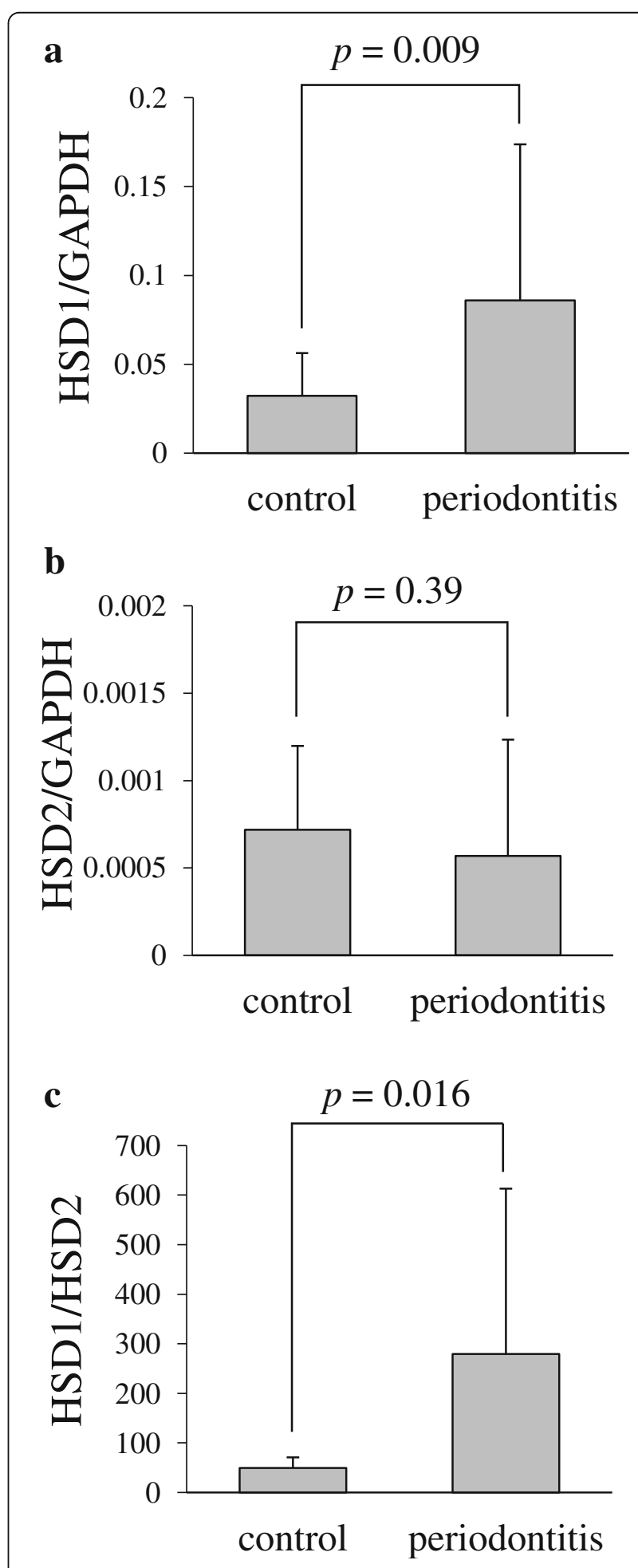

Fig. 2 The expression of $11 \beta$-HSD1 mRNA is increased in the ligature-induced periodontitis compared with the control. a The values of $11 \beta$-HSD 1 mRNA relative to GAPDH mRNA. $\mathbf{b}$ The values of $11 \beta-H S D 2$ mRNA relative to GAPDH mRNA. $\mathbf{c}$ The ratio of $11 \beta-H S D 1$ versus $11 \beta-H S D 2$ mRNA. Values are expressed as mean + standard deviation $(n=16)$ 


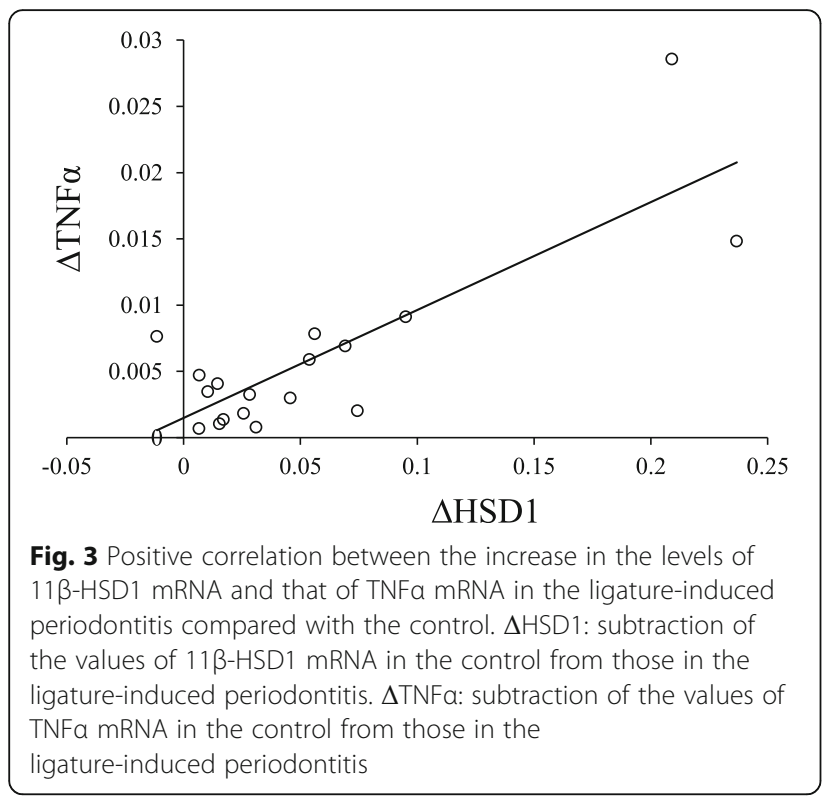

Fig. 3 Positive correlation between the increase in the levels of $11 \beta-H S D 1$ mRNA and that of TNFa mRNA in the ligature-induced ligature-induced periodontitis. $\triangle T$ TNFa: subtraction of the values of TNFa mRNA in the control from those in the ligature-induced periodontitis

\section{Results}

Experimental periodontitis was induced by ligature placement, and alveolar bone loss due to ligature-induced periodontitis was observed after 2 weeks (Fig. 1).

To investigate the involvement of $11 \beta$-HSD1 in experimental periodontitis, the expression of $11 \beta-H S D 1$, as well as $11 \beta$-HSD2 mRNA, in periodontal tissues was analysed by the real time RT-PCR method. The expression of TNF $\alpha$ mRNA in periodontal tissues was concurrently examined to confirm the induction of periodontitis by ligature placement. Thus, the data of rats $(n=16)$ in which the levels of TNF $\alpha$ mRNA were increased more than 1.4fold in the ligature-induced periodontitis compared with the control were analysed. The levels of $11 \beta-H S D 1$ mRNA were significantly higher in periodontal tissues around the left maxillary second molars than in those around the right ones (Fig. 2a), whereas the levels of $11 \beta$-HSD2 mRNA were slightly, but not significantly, lower in the former than in the latter (Fig. 2b). Therefore, the ratio of $11 \beta$-HSD1 versus $11 \beta$-HSD2 mRNA was significantly higher in the former than in the latter (Fig. 2c), which is consistent with the results we recently reported using human periodontal tissues.
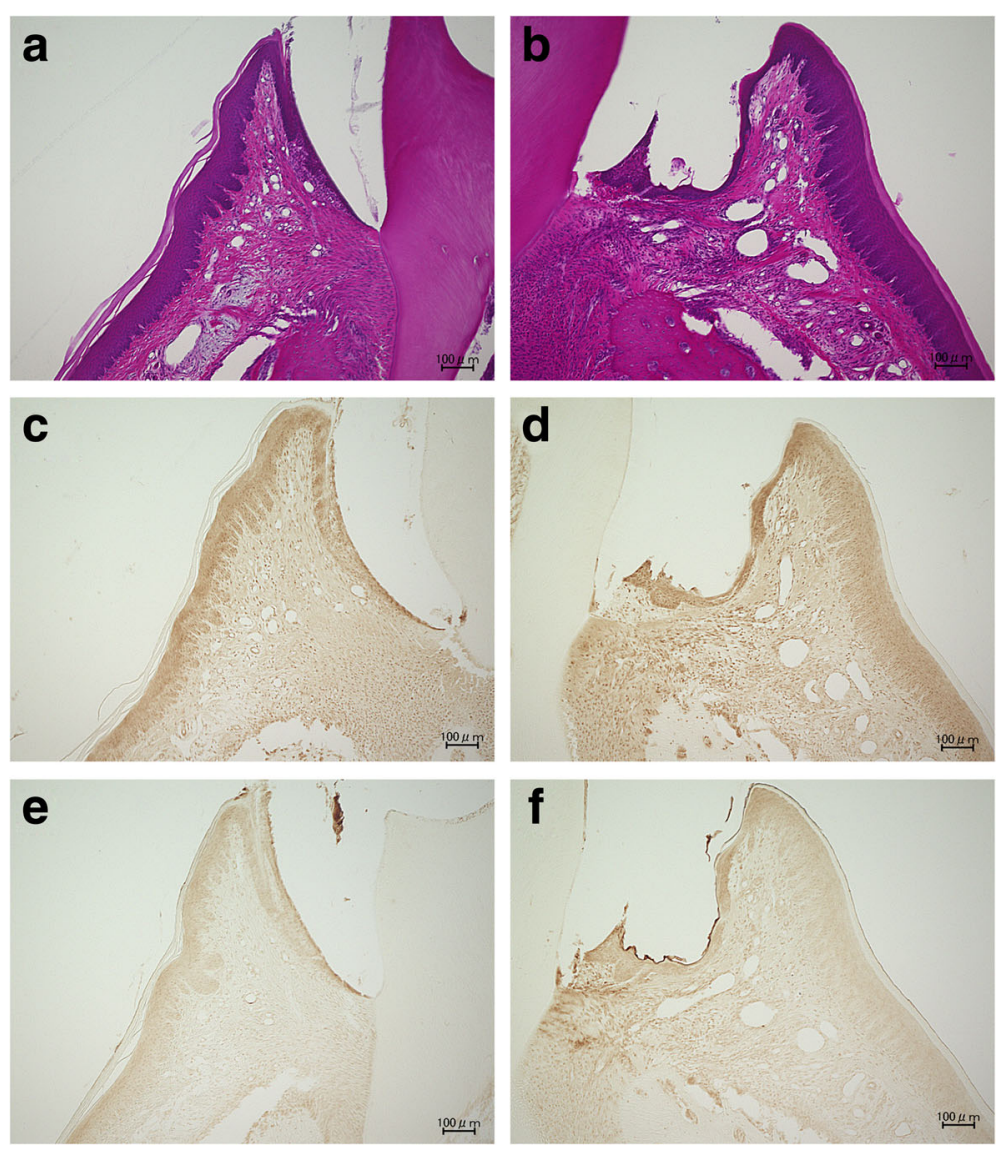

Fig. 4 Histological examination of $11 \beta-H S D 1$ and $11 \beta-H S D 2$ expression (at lower magnification). a, b HE staining. $\mathbf{c}$, d Immunostaining with

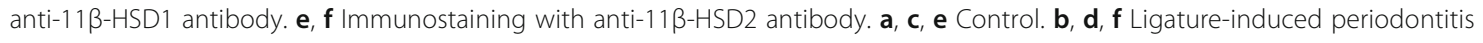


The increase in $11 \beta-H S D 1$ mRNA in the ligatureinduced periodontitis compared with the control was positively correlated with that in TNF $\alpha$ mRNA $(p=0.000$ by significance testing of Pearson's correlation coefficient) (Fig. 3).

Histological examinations revealed that the expression of $11 \beta-H S D 1$ protein was increased in the ligatureinduced periodontitis, especially in the infiltrating neutrophils in gingival lamina propria, compared with the control (Figs. 4 and 5), which is in accordance with a recent report demonstrating that $11 \beta-H S D 1$ is highly expressed in neutrophils [33]. The expression of $11 \beta-H S D 2$ protein was not apparently different between the control and ligature-induced periodontitis.

\section{Discussion}

The close relationship between increased glucocorticoids and chronic periodontitis has been reported. Since glucocorticoids are increased during stress due to activation of the HPA axis, several studies have reported that chronic periodontitis is associated with stress $[1,2,5]$. In contrast, we have recently reported that human chronic periodontitis is associated with the increased expression of $11 \beta-H S D 1$, as well as the increased ratio of $11 \beta-H S D 1$ versus $11 \beta-H S D 2$ mRNA, which would result in the increased levels of intracellular glucocorticoids [31]. In this study, we demonstrated that the expression of $11 \beta-H S D 1$, as well as the ratio of $11 \beta-H S D 1$ versus $11 \beta-H S D 2$ mRNA, is increased in ligature-induced periodontitis in rats. These results suggest that the increased intracellular glucocorticoids may play a role in the pathogenesis of chronic periodontitis independent of the HPA axis.

$11 \beta$-HSD1 has been reported to be involved in metabolic diseases, including obesity [13-15]. However, we recently reported that increases in $11 \beta-\mathrm{HSD} 1 \mathrm{mRNA}$, as well as the ratio of $11 \beta-H S D 1$ versus $11 \beta-H S D 2$ mRNA, were associated with chronic periodontitis, irrespective of obesity in human subjects [31]. Since obesity, as well as metabolic diseases, can be regarded as chronic inflammation of adipose tissue $[25,26]$, and the increased expression of 11ß-HSD1 has been demonstrated in chronic inflammatory diseases such as inflammatory bowel diseases and rheumatoid arthritis [27-30], these results suggest that the increased $11 \beta$-HSD1 plays a role in chronic
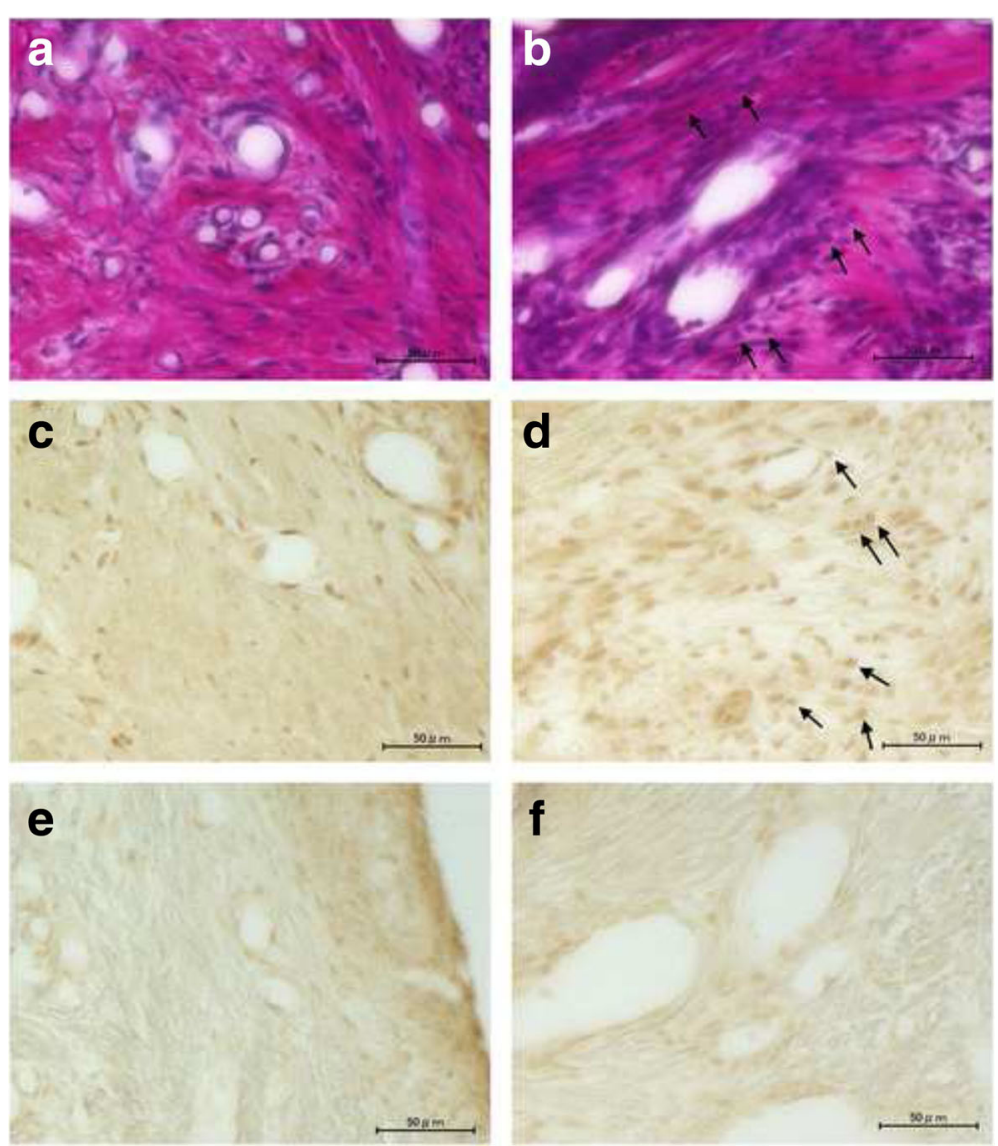

Fig. 5 Histological examination of $11 \beta-H S D 1$ and 11 1 -HSD2 expression (at higher magnification). a, b HE staining. $\mathbf{c}$, d Immunostaining with anti-11ß-HSD1 antibody. e, $\mathbf{f}$ Immunostaining with anti-11ß-HSD2 antibody. $\mathbf{a}, \mathbf{c}, \mathbf{e}$ Control. $\mathbf{b}, \mathbf{d}$, $\mathbf{f}$ Ligature-induced periodontitis. Some of the infiltrating neutrophils, which are immunostained with anti-11 -HSD1 antibody, are indicated by the arrows 
inflammation. The increased expression of $11 \beta$-HSD1 in chronic periodontitis in human subjects, as well as in ligature-induced periodontitis in rats, seems to be in accordance with this notion.

The precise role of the increased $11 \beta-H S D 1$ in chronic inflammation remains to be determined. Although glucocorticoids have strong anti-inflammatory effects [34] pro-inflammatory effects of glucocorticoids have been reported, especially in chronic inflammation [12, 30]. Furthermore, the pro-inflammatory role of $11 \beta$-HSD1 have been demonstrated $[35,36]$. Thus, overexpression of $11 \beta$-HSD1 augmented TNF $\alpha$-induced iNOS, IL-6, and MCP-1 expression, whereas $11 \beta-H S D 1$ inhibitors attenuated TNF $\alpha$-induced NF-kB and MAPK signaling pathways. In this study, the increase in the levels of $11 \beta$-HSD1 mRNA was proportional to that of TNF $\alpha$ mRNA, indicating the extent of inflammation (Fig. 3), which is consistent with the pro-inflammatory role of $11 \beta$-HSD1 and glucocorticoids. However, the causal relationship between the increased 11 $\beta-H S D 1$ expression and chronic inflammation, including chronic periodontitis, needs to be determined using specific $11 \beta$-HSD1 inhibitors or gene knockout animals.

\section{Conclusions}

We demonstrated for the first time that, to the best of our knowledge, the expression of $11 \beta$-HSD1 mRNA is increased in experimental periodontitis in animals. This is in agreement with our recent report that the expression of $11 \beta-H S D 1$ is increased in chronic periodontitis in human subjects irrespective of obesity, suggesting that the increased expression of $11 \beta$-HSD1, which would result in in the increased levels of intracellular glucocorticoids, may play a role in the pathogenesis of chronic periodontitis independent of the HPA axis. Further investigation is required to elucidate the precise role of $11 \beta$-HSD1 in chronic periodontitis.

\section{Abbreviations}

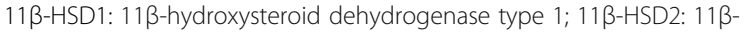
hydroxysteroid dehydrogenase type 2; GAPDH: Glyceraldehyde-3-phosphate dehydrogenase; HE: Hematoxylin-eosin; HPA: Hypothalamic-pituitary-adrenal; PCR: Polymerase chain reaction; RT: Reverse transcription

\section{Acknowledgements}

The authors thank Atsuko Fujita for her contribution to this study.

\section{Funding}

This work was supported in part by a Grant-in-Aid for Scientific Research (C) from Japan Society for the Promotion of Science \#25462941 (to H.S.).

\section{Availability of data and materials}

The datasets generated or analysed during the current study available from the corresponding author on reasonable request.

\section{Authors' contributions}

TN performed RT-PCR and histological examinations. MU, HM and HS designed the study. HS wrote the manuscript. All authors read and approved the final manuscript.

\section{Competing interests}

The authors declare that they have no competing interests.

Consent for publication

Not applicable.

Ethics approval and consent to participate

The experimental protocol was approved by the Committee for Animal Experiments of Osaka Dental University (\#14-09001), and experimental procedures were performed in accordance with the Guidelines for Animal Experiments of Osaka Dental University.

\section{Author details}

'Department of Periodontology, Graduate School of Dentistry, Osaka Dental University, Hirakata, Osaka, Japan. ${ }^{2}$ Department of Periodontology, Osaka Dental University, Hirakata, Osaka, Japan. ${ }^{3}$ Division of Endocrinology, Diabetes and Metabolism, Hematology, Rheumatology, Graduate School of Internal Medicine, University of the Ryukyus, Nakagami-gun, Okinawa, Japan.

${ }^{4}$ Department of Internal Medicine, Osaka Dental University, Hirakata, Osaka, Japan.

Received: 5 July 2016 Accepted: 22 September 2016

Published online: 03 October 2016

\section{References}

1. Genco RJ, Ho AW, Kopman J, Grossi SG, Dunford RG, Tedesco LA. Models to evaluate the role of stress in periodontal disease. Ann Periodontol. 1998;3:288-302.

2. Hilgert JB, Hugo FN, Bandeira DR, Bozzetti MC. Stress, cortisol, and periodontitis in a population aged 50 years and over. J Dent Res. 2006;85:324-8.

3. Ishisaka A, Ansai T, Soh I, Inenaga K, Yoshida A, Shigeyama C, et al. Association of salivary levels of cortisol and dehydroepiandrosterone with periodontitis in older Japanese adults. J Periodontol. 2007;78:1767-73.

4. Ishisaka A, Ansai T, Soh I, Inenaga K, Awano S, Yoshida A, et al. Association of cortisol and dehydroepiandrosterone sulphate levels in serum with periodontal status in older Japanese adults. J Clin Periodontol. 2008:35:853-61.

5. Rosania AE, Low KG, McCormick CM, Rosania DA. Stress, depression, cortisol, and periodontal disease. J Periodontol. 2009:80:260-6.

6. Breivik T, Opstad PK, Gjermo P, Thrane PS. Effects of hypothalamic-pituitaryadrenal axis reactivity on periodontal tissue destruction in rats. Eur J Oral Sci. 2000;108:115-22.

7. Breivik T, Thrane PS, Gjermo P, Opstad PK. Glucocorticoid receptor antagonist RU 486 treatment reduces periodontitis in Fischer 344 rats. J Periodontal Res. 2000;35:285-90.

8. Breivik T, Thrane PS, Gjermo P, Opstad PK, Pabst R, von Hörsten S. Hypothalamic-pituitary-adrenal axis activation by experimental periodontal disease in rats. J Periodontal Res. 2001:36:295-300.

9. Livingstone DE, Jones GC, Smith K, Jamieson PM, Andrew R, Kenyon CJ, et al. Understanding the role of glucocorticoids in obesity: tissue-specific alterations of corticosterone metabolism in obese Zucker rats. Endocrinology. 2000;141:560-3.

10. Seckl JR, Walker BR. Minireview: 11ß-hydroxysteroid dehydrogenase type 1 - a tissue-specific amplifier of glucocorticoid action. Endocrinology. 2001;142:1371-6.

11. Tomlinson JW, Walker EA, Bujalska IJ, Draper N, Lavery GG, Cooper MS, et al. 11ß-hydroxysteroid dehydrogenase type 1: a tissue-specific regulator of glucocorticoid response. Endocr Rev. 2004;25:831-66.

12. Chapman KE, Coutinho AE, Zhang Z, Kipari T, Savill JS, Seckl JR. Changing glucocorticoid action: 11 $\beta$-hydroxysteroid dehydrogenase type 1 in acute and chronic inflammation. J Steroid Biochem Mol Biol. 2013;137:82-92.

13. Bujalska IJ, Kumar S, Stewart PM. Does central obesity reflect 'Cushing's disease of the omentum'? Lancet. 1997;349:1210-3.

14. Rask E, Olsson T, Söderberg S, Andrew R, Livingstone DE, Johnson O, et al. Tissue-specific dysregulation of cortisol metabolism in human obesity. J Clin Endocrinol Metab. 2001:86:1418-21.

15. Paulsen SK, Pedersen SB, Fisker S, Richelsen B. 11ß-HSD type 1 expression in human adipose tissue: impact of gender, obesity, and fat localization. Obesity. 2007;15:1954-60

16. Kotelevtsev $Y$, Holmes MC, Burchell A, Houston PM, Schmoll D, Jamieson $P$, et al. $11 \beta$-hydroxysteroid dehydrogenase type 1 knockout mice show 
attenuated glucocorticoid-inducible responses and resist hyperglycemia on obesity or stress. Proc Natl Acad Sci U S A. 1997;94:14924-9.

17. Masuzaki H, Paterson J, Shinyama H, Morton NM, Mullins JJ, Seckl JR, et al. A transgenic model of visceral obesity and the metabolic syndrome. Science. 2001;294:2166-70.

18. Masuzaki H, Yamamoto H, Kenyon CJ, Elmquist JK, Morton NM, Paterson JM, et al. Transgenic amplification of glucocorticoid action in adipose tissue causes high blood pressure in mice. J Clin Invest. 2003;112:83-90

19. Hermanowski-Vosatka A, Balkovec JM, Cheng K, Chen HY, Hernandez M, Koo GC, et al. 11ß-HSD1 inhibition ameliorates metabolic syndrome and prevents progression of atherosclerosis in mice. J Exp Med. 2005;202:517-27.

20. Nuotio-Antar AM, Hachey DL, Hasty AH. Carbenoxolone treatment attenuates symptoms of metabolic syndrome and atherogenesis in obese, hyperlipidemic mice. Am J Physiol Endocrinol Metab. 2007;293:E1517-28.

21. Rosenstock J, Banarer S, Fonseca VA, Inzucchi SE, Sun W, Yao W, et al. The 11- $\beta$-hydroxysteroid dehydrogenase type 1 inhibitor INCB13739 improves hyperglycemia in patients with type 2 diabetes inadequately controlled by metformin monotherapy. Diabetes Care. 2010;33:1516-22.

22. Feig PU, Shah S, Hermanowski-Vosatka A, Plotkin D, Springer MS, Donahue S, et al. Effects of an $11 \beta$-hydroxysteroid dehydrogenase type 1 inhibitor, MK-0916, in patients with type 2 diabetes mellitus and metabolic syndrome. Diabetes Obes Metab. 2011;13:498-504.

23. Anil TM, Dandu A, Harsha K, Singh J, Shree N, Kumar VS, et al. A novel 11ß-hydroxysteroid dehydrogenase type1 inhibitor CNX-010-49 improves hyperglycemia, lipid profile and reduces body weight in diet induced obese C57B6/J mice with a potential to provide cardio protective benefits. BMC Pharmacol Toxicol. 2014;15:43.

24. Okazaki S, Takahashi T, Iwamura T, Nakaki J, Sekiya Y, Yagi M, et al. HIS-388, a novel orally active and long-acting $11 \beta$-hydroxysteroid dehydrogenase type 1 inhibitor, ameliorates insulin sensitivity and glucose intolerance in diet-induced obesity and nongenetic type 2 diabetic murine models. J Pharmacol Exp Ther. 2014;351:181-9.

25. Hotamisligil GS. Inflammation and metabolic disorders. Nature. 2006;444:860-7.

26. Grant RW, Dixit VD. Adipose tissue as an immunological organ. Obesity. 2015;23:512-8

27. Zbánková S, Bryndová J, Leden P, Kment M, Svec A, Pácha J. 11ß-hydroxysteroid dehydrogenase 1 and 2 expression in colon from patients with ulcerative colitis. J Gastroenterol Hepatol. 2007;22:1019-23.

28. Hardy R, Rabbitt EH, Filer A, Emery P, Hewison M, Stewart PM, et al. Local and systemic glucocorticoid metabolism in inflammatory arthritis. Ann Rheum Dis. 2008;67:1204-10.

29. Stegk JP, Ebert B, Martin H-J, Maser E. Expression profiles of human $11 \beta$-hydroxysteroid dehydrogenases type 1 and type 2 in inflammatory bowel diseases. Mol Cell Endocrinol. 2009;301:104-8.

30. Hardy RS, Raza K, Cooper MS. Glucocorticoid metabolism in rheumatoid arthritis. Ann N Y Acad Sci. 2014;1318:18-26.

31. Nakata T, Fujita A, Umeda M, Yoshida H, Inami K, Masuzaki H, et al. The increased ratio of $11 \beta$-hydroxysteroid dehydrogenase type 1 versus $11 \beta$-hydroxysteroid dehydrogenase type 2 in chronic periodontitis irrespective of obesity. SpringerPlus. 2016;5:40.

32. Coimbra LS, Steffens JP, Muscara MN, Rossa Jr C, Spolidorio LC. Antiplatelet drugs reduce the immunoinflammatory response in a rat model of periodontal disease. J Periodontal Res. 2014;49:729-35.

33. Coutinho AE, Kipari TM, Zhang Z, Esteves CL, Lucas CD, Gilmour JS, et al, $11 \beta$-Hydroxysteroid dehydrogenase type 1 is expressed in neutrophils and restrains an inflammatory response in male mice. Endocrinology. 2016;157:2928-36

34. Rhen T, Cidlowski JA. Antiinflammatory action of glucocorticoids - new mechanisms for old drugs. N Engl J Med. 2005:353:1711-23.

35. Ishii T, Masuzaki H, Tanaka T, Arai N, Yasue S, Kobayashi N, et al. Augmentation of $11 \beta$-hydroxysteroid dehydrogenase type 1 in LPS-activated J774.1 macrophages - role of $11 \beta$-HSD1 in pro-inflammatory properties in macrophages. FEBS Lett. 2007;581:349-54.

36. Ishii-Yonemoto T, Masuzaki H, Yasue S, Okada S, Kozuka C, Tanaka T, et al. Glucocorticoid reamplification within cells intensifies NF-kB and MAPK signaling and reinforces inflammation in activated preadipocytes. Am J Physiol Endocrinol Metab. 2010;298:E930-40.

\section{Submit your next manuscript to BioMed Central and we will help you at every step:}

- We accept pre-submission inquiries

- Our selector tool helps you to find the most relevant journal

- We provide round the clock customer support

- Convenient online submission

- Thorough peer review

- Inclusion in PubMed and all major indexing services

- Maximum visibility for your research

Submit your manuscript at www.biomedcentral.com/submit

) Biomed Central 